\title{
ORGANIZATIONAL LEARNING, PRACTICES OF DIVERSITY, AND CEREMONIALISM: A STUDY PROPOSAL IN THE MULTINATIONALS CONTEXT
}

\author{
PAULA SUEMI SOUZA KUABARA \\ Universidade Federal do Paraná (UFPR), Paraná - PR, Brazil. \\ ADRIANA ROSELI WÜNSCH TAKAHASHI \\ Universidade Federal do Paraná (UFPR), Paraná - PR, Brazil.
}

To cite this paper: Kuabara, P. S. S. \& Takahashi, A. R. W. (2017). Organizational learning, practices of diversity, and ceremonialism: a study proposal in the multinationals context. Revista de Administração Mackenzie, 18(5), 169-201. doi 10.1590/1678-69712017/administracao. v18n5p169-201 


\section{ABSTRACT}

Purpose: to articulate the categories of organizational learning, diversity of practice, and ceremonialism in the context of multinational companies. Originality/value: Learning perspective as a procedural phenomenon and intervention factors such as ceremonialism may potentiate or hinder the organizational learning process, contributing to new insights for both multinational organizations and organizational learning research.

Design/methodology/approach: a theoretical essay that proposes an integration of the categories of organizational learning, diversity practices, and ceremonialism in the context of multinational companies.

Findings: This work contributes to the construction of a research model with a proposal for studies of organizational learning, diversity practices, and ceremonialism in the context of multinational companies.

\section{KEYWORDS}

Organizational learning. Organizational knowledge. Ceremonialism. Diversity practices. Multinationals.

\section{INTRODUCTION}

This essay analyzes knowledge flow in learning and the interaction process between organizational members that guides and modifies patterns of organizational action and knowledge from the social perspective. According to this perspective, learning is not only achieved through actors' participation but is also constantly modified by interaction (Elkjaer, 1999) so that changes are observed both in the order and in the regulations of actions and practices (Chiva, Alegre, \& Lapiedra, 2007; Gherardi, 2003). 
Considering social interactions in the construction of knowledge in the organization, another important factor that has been the subject of recent discussions is the importance of the context in which learning takes place (Argote, 2011; Ramos Filho, 2012; Roth \& Kostova, 2003). As Argote (2011) highlights, context is an important factor for learning, because it contributes to the understanding of actions, experiences, and interaction between actors in the construction of organizational knowledge.

To be part of an institutional environment, the organization outlines its strategies and defines the practices necessary to its actions based on a learning process in which both the strategies outlined and the values are fed back in this interaction. Often, strategically significant knowledge is embedded in and sustained by the organizational culture. However, the meaning of knowledge can be distorted and its usefulness diminished when actors inserted in a different context do not perceive what the organization aims to achieve by sharing specific knowledge (Easterby-Smith, Lyles, \& Tsang, 2008).

This knowledge-sharing process is perceived in different locations in the dynamics of the relationships of multinational companies. The distinction of a multinational in a given context permeates its capacity for innovation in products, production, and organizational processes, which is embedded in the organizational system and its human resources (Figueiredo, 2011). Sharing knowledge across geographical boundaries can be a further complication because it involves different cultures and can influence how people process, interpret, and use knowledge (Easterby-Smith et al., 2008).

When the adoption of new practices demanded by the external environment is necessary for its legitimacy and the organization does not consider that the changes will bring economic and efficiency benefits to its production process, it can adopt ceremonial practices to validate its performance toward the environment (Meyer \& Rowan, 1977). The perspective of ceremonialism (Meyer \& Rowan, 1977) is included in this essay as a category that contributes to understanding the organizational learning process in terms of how multinationals face the process of internal and external pressure, the need for conformity and legitimacy vis-à-vis the environment in which it operates, and the ability to share practices between the parent and the subsidiary.

In order to operationalize the identified problem, practices were chosen that are related to the inclusion of people with disabilities (PWD) located in the area of diversity management, which began in Brazil with changes in the competitive environment in the 1990s. The diversity practices analyzed are therefore specifically related to PWD, as seen in Brazilian law. This law can 
be considered an external demand that influences practices in organizations that operate in the Brazilian context.

Although discussions on diversity in organizations have always followed a discourse about its importance for the achievement of organizational challenges and the search for competitive advantages due to openness to different points of view (Alves \& Galeão-Silva, 2004; Fernandes \& Silva, 2008; Gil, 2002; Perlin, Gomes, Kneipp, Frizzo, \& Rosa, 2016), the diversification of the workforce through the inclusion of PWD is not yet a "desire of many organizations" (Fernandes \& Silva, 2008, p. 187). According to Ribeiro and Carneiro (2009), the institutional fragility observed in Brazil constitutes one of the points that favor non-conformity with the quota law, allowing organizations to adopt permissive conducts, considering that the legal norms are contrary to their interests.

Given this scenario of inclusion observed in Brazil and the proposed categories, this essay proposes a theoretical model for the study of the organizational learning process that permeates the development of diversity practices in Brazilian subsidiaries, considering the legal context of the headquarters and the presence of ceremonial practices. Thus, from the legal demand, it is possible to identify the flow of organizational knowledge for the absorption or creation of diversity practices from the headquarters to the subsidiary, and what knowledge was created or abandoned in the process of including diversity in the organizational context.

\section{ORGANIZATIONAL LEARNING}

In general, organizational learning (OL) is defined as the process by which organizations learn (Chiva, Alegre, \& Lapiedra, 2007; Crossan, Maurer, \& Lane, 1999; Fiol \& Lyles, 1985). This process is permeated by interactions between organizational members through the socialization of learning and practices considered as a collective achievement (Fiol \& Lyles, 1985; Gherardi \& Nicolini, 2002). Knowledge resulting from these interactions is institutionalized in stable mechanisms (Gherardi, 1999; Patriotta, 2003; Shrivastava, 1983).

Knowledge, when shared among organizational members, can be incorporated into the organization so that other members can have access to that knowledge, even when the individual leaves the organization (Argote, 2011). Shared knowledge remains embedded in the organizational systems, structures, and culture of the organization (Dyck, Starke, Mischke, \& Mauws, 
2005; Patriotta, 2003; Takahashi, 2007). For Takahashi (2007, p. 88), learning can be considered a "process of transformational change, involving the various levels (individuals, groups, and organization), through which the creation, utilization, and institutionalization of knowledge take place. It operates collectively, encompassing cognitive, behavioral, and cultural aspects".

The way the organization deals with events is subject to multiple interpretations that define the actions of individuals and how they seek to make learning meaningful. Thus, learning involves the connection of different meanings, schemes, and actions between actors and their environment, providing a purpose for how they interact and how they explore the interdependencies of organizational knowledge (Antonacopolou \& Chiva, 2007).

It is assumed here that knowledge is a process of being and becoming. To understand how the OL process occurs, it is necessary to analyze the construction of knowledge as a historical, material, and cultural process in the organization as a whole. In this sense, the learning process involves knowledge creation and knowledge sharing, which occurs through interactions between individuals and with the environment. Learning is considered collective when it is perceived at the level of social interaction and this process does not only occur in the context of the individual's cognition but is also dependent on the context in which it is inserted.

Thus, it is considered that OL is a process of collective knowledge construction and change that is produced and modified through practices, incorporating not only cognitive but also social and behavioral aspects. The dynamic and integrative aspect of practices and the learning process in organizations point to the fact that learning does not occur in a vacuum; rather, it is related to the events that occur within a given context. To understand how practice is seen in relation to OL, it is necessary to explore this dimension in more depth.

\section{PRACTICE-BASED LEARNING}

In organizational studies, the influence of the perspective of practice has been seen both as a lens for the studies of different organizational phenomena and as an epistemology for the study of work practices, the type of practice, and the knowledge that sustains it. OL and studies of knowing appropriated the concept of practice from the late 1990s and early 2000s. This theoretical movement allowed for a change in the concepts used in the theoretical body of OL, starting with a new understanding of the concept of 
knowledge as knowing, conceiving it as a practical activity. Thus, knowledge can be considered to reside in social relations, while knowing is part of a movement to become a member of a practice (Gherardi, 2001). In addition, Geiger (2009) emphasizes that the creation of knowledge happens at the moment of practice and, in view of this, knowledge and practice cannot be considered separate elements in the learning process in organizations.

Thinking about learning through the participation of the actors in practice makes it possible to focus the attention of studies on the fact that learning occurs in the daily practices, based on the flow of experience with or without the participants' awareness. Engaging in a practice is consequently a way of acquiring knowledge in action, but also of changing or perpetuating that knowledge, of producing and reproducing society (Gherardi, 2000).

In this essay, we consider Gherardi's (1999) argument that learning is an integral and inseparable part of all organizational practices. In this sense, organizational learning can be considered a heuristic mechanism used to study how knowledge is socially constructed in organizational practices and that goes beyond the formal limits of organizations. It is the interactive movement that enables actors to modify their relationships with others while contributing to the knowledge already established for shared activities.

In this way, learning within organizations can be conceived as a social process with the purpose of finding out what people do, when they do it, and how they do it, guided by observation of their routines and the use of specific artifacts to explain why it was done (Gherardi \& Nicolini, 2002). Here lies the potential of considering practices as elements of analysis in learning studies in this perspective, since they are imbricated with knowledge and gain concreteness in social interaction. When considering the aspects involved in the learning process and the interactive and integrative role of the actors involved, the discussion presented here is based on the understanding of learning and the dynamics of organizational practices.

Positioning the learning process from the practice studies allows us to improve the understanding of knowledge production and its reproduction circuit within social relations (Gherardi, 2009b; Raelin, 2007). This is due to the fact that, in order to understand the flow of knowledge in the organization, it is necessary to question where and why practices (embodied within certain circumstances) are common and where and why they are not (Brown \& Duguid, 2001). In this way, the organizational capacity of organizational actors is recognized, although other organizational and environmental dimensions (contextual, economic, social, and cultural) act as constraints or limiters of this capacity. 
The incorporation of practices into new geographical and cultural contexts finds fertile ground for analysis in the dynamics of multinational enterprises (MNEs), which, when establishing themselves in locations with characteristics different from their origin, need to learn about the sociocultural environment of the subsidiary and to reconcile internal interests with environmental pressures. Contextual differences guide organizational identification, and one aspect to be emphasized is the relationship between how employees think of themselves and how they perceive the organization as a whole (Gertsen \& Zolner, 2014). This process can influence how practices are distributed and accepted outside their place of origin.

It can be considered that there are tensions in the interaction between the members as to the form of sharing of institutionalized practices that the organizations try to reproduce when entering a new context. One aspect that interferes in practice sharing is the understanding of the culture of the countries involved and associated cultural practices. One of the key issues in business theory and practice in relation to internationalization is the alignment of MNEs' policies and practices between different business systems in the countries in which they operate.

The sharing of knowledge created in another location and within a different context is a process whose complexity lies in the need to transmit between two institutional domains that differ in important aspects. Such differences go beyond those found in the same business, within a single national space, raising questions about how practices originating in one national institutional sphere are incorporated into a significantly different one (Phillips \& Tracey, 2009).

In this sense, practice analysis provides a complete view of institutional duality, its causes and its effects on MNEs, and how the interaction between individuals of different cultures can influence the sharing of practices and the learning process that permeates the entry of an organization into a new country (Muzio \& Faulconbridge, 2013). Thus, we focus next on intra-organizational knowledge sharing that involves the multifaceted nature of the geographic boundaries, cultures, and processes involved, as in the case of MNEs.

\section{INTRA-ORGANIZATIONAL KNOWLEDGE SHARING}

Organizational knowledge can be defined as the knowledge and information held by an organization that is shared by all or part of the organization and often converted into standard operating procedures, 
routines, rules, or in the minds of organizational members (Levitt \& March, 1988; Schulz, 2003). Considered as a valuable resource for the organization, the ability to leverage its resources through the sharing of knowledge at the global level is considered by scholars to be the true raison d'être of an MNE (Ambos \& Ambos, 2009; Easterby-Smith et al., 2008).

For the construction of knowledge from the actions of geographically dispersed members, people from MNE functional units need to share knowledge with each other. This means that the MNE as a whole needs to be able to share that knowledge within organizational networks characterized by the separation of time, space, context, culture, and language (Ambos \& Ambos, 2009; Gertsen \& Zølner, 2014; Kostova, 1999; Søderberg \& Holden 2002; Vaara, Risberg, Søderberg, \& Tienari, 2003).

Historically, as Achcaoucou, Miravitlles, and Léon-Darder (2014) point out, the head offices have always been considered the only source of competitive advantage for an MNE because they are primarily responsible for the organizational leverage, sharing their consolidated knowledge with the foreign subsidiaries. However, due to the greater integration of the subsidiaries in international networks, the latter have been able to generate new knowledge for the entire MNE. As argued by Ambos and Ambos (2009), Kasper, Lehrer, Mühlbacher and Müller (2013), and Schulz (2003), something that differentiates the knowledge to share policy is the subsidiary's level of freedom in creating and sharing local knowledge and how much the global hierarchy influences the knowledge of the units.

In general, Schulz (2003) considers that knowledge in MNEs can flow according to the place where certain knowledge is considered relevant. However, regardless of how the MNE perceives the need for knowledge sharing, Schulz (2003) points to other factors that may prevent relevant knowledge from being shared by the subsidiary, such as learning barriers, "not invented" syndrome, and the stickiness of knowledge. To understand the organizational identification of individuals, one must consider the cultural and social contexts in which the interaction among individuals occurs.

This contextualization is of increasing relevance for understanding how companies are internationalized and assign more functions to their subsidiaries in different parts of the world, with geographic and sociocultural distances between units and employees. Thus, it is possible to perceive that the internationalization process leads to an increasing number of companies and individuals in the subsidiaries facing the challenge of cross-cultural organizational identification. 
The issues addressed here can be considered relevant to the expansion of multinationals in new contexts. One of the topics covered in the literature on cross-culture concerns diversity in the most different aspects related to individuals and their interactions. Diversity can be seen through the social identities that carry with them a particular history, built within a historical, social, and economic context that guides culture and stereotypes (Boyle, Nicholas, \& Mitchell, 2012; Gertsen \& Zølner, 2014; Kostova, 1999). Determining which specific sociodemographic dimensions are most relevant to an organization that is highly dependent on the wider community and national contexts is a factor to be considered by multinationals (Shen \& Benson, 2014).

Organizational learning of practices related to diversity is the focus of this essay; therefore the aspects highlighted here between learning and inter-organizational knowledge in MNEs will be directed to the analysis of these practices. Given the need to include individuals in the work environment, organizations can use different practices for more effective diversity management (Yang \& Konrad, 2011). Thus, diversity practices can be perceived as substantive organizational efforts to build an inclusive culture that values differences and promotes opportunities for all employees (Esen, 2005).

Considering practice-based learning, the construction of knowledge about diversity inclusion emphasizes the concept of socially constructed practice, embodied in the characteristics and interactions among organizational actors that lead to the reproduction of society. The refinement or abandonment of a practice depends on constant negotiation between the actors and the intersubjectively constructed meaning (Gherardi, 2009b). Thus, the focus of the research is on understanding how organizations construct their vision and actions for inclusion, how decisions are made, and how the construction of knowledge about diversity occurs. Before moving forward with this theoretical reflection, it is important to contextualize how the inclusion of PWD is part of the management of diversity and how its regulation occurs in Brazil so that one can understand how a normative pressure can be interpreted by MNEs that need to adapt to the new environment.

\section{DIVERSITY MANAGEMENT}

Some scholars define diversity management as the proactive attitude of an organization to insert diversity, regardless of the dimension-race, 
gender, ethnicity, sexual orientation, or disability (Brdulak, 2008; Cox \& Beale, 1997; Spataro, 2005; Thomas \& Ely 1996). In a narrow conception, diversity management can be seen as the successor to affirmative actions (AAs) or equal opportunity programs used in different countries focusing on specific social groups. From this perspective, the hiring of people belonging to these groups is carried out based on the regulations and procedures of the organization. On the other hand, from a broader perspective, diversity management is seen as an inclusive approach with the aim of attracting new people. This latter view proposes a greater understanding of individual differences, which include factors such as gender, sexual orientation, abilities, origin, ethnicity, education, and experience.

In this work, it is assumed, according to Yang and Konrad (2011), that diversity management, besides involving proactive actions, also includes actions of equal employment and AA programs, as well as incorporating the criterion of external pressure and regulation of the insertion of diversity in the organizational context. Whatever the perspective used to define diversity management, it will influence the implementation, rules, and arguments that guide the practice of diversity management programs (Bleijenbergh, Peters, \& Poutsma, 2010). According to the authors, the insertion of diversity often involves the removal of obstacles to the employment of historically marginalized groups.

This is the case of AAs, initiated in the United States since the 1960s, which regulate the inclusion of women, blacks, Hispanics, Asians, and Native Americans to broaden their representation in organizations; the Employment Equality Initiative in Canada in the mid-1980s, aimed at eliminating barriers and expanding the representation of women, racial minorities, people with disabilities, and Aboriginal people in the labor market (Agócs \& Burr, 1996); or the policy quota for PWD in Brazil, a segment of diversity management discussed in the country since the beginning of the 1990s whose practices are portrayed here as an example of legal pressure for inclusion in organizations. To illustrate the inclusion of diversity from a normative approach, this paper exemplifies the case of PWD in the organizational context that has its own regulation in Brazil.

The insertion of PWD in Brazil, in its nature, is characterized by institutional pressures, and its understanding demands knowledge of organizational structures and actions, as well as of the social environment (Martinez \& Dacin, 1999). In Brazil, the inclusion of PWDs in the labor market takes place through a law established in the Federal Constitution, promulgated in 1988. Law No. 8,213/91 provides for the reservation of 
between two percent and five percent of their positions for rehabilitated beneficiaries or eligible PWDs.

Data from the Brazilian Institute of Geography and Statistics (IBGE, 2012) show that in 2010, 45.6 million people reported having some kind of disability, which represents about 23.9 percent of the Brazilian population. Of the share of the population of PWD in Brazil, the Annual Social Information Report (RAIS, 2012) found that 381,322 workers' employment was declared as PWD, corresponding to approximately 0.77 percent of total employment in the country.

Given a large number of PWDs in Brazil, Belizário (2009) questions why many companies report difficulty in filling quotas. On the part of employers, there is a discourse that questions legal inflexibility, such as the setting of percentages and the difficulty of finding people with adequate qualifications (Simonelli \& Camaroto, 2011). Added to this prejudice is a lack of knowledge about disability, which prevents a different posture of organizations to favor a more humane and democratic environment (Fernandes \& Silva, 2008; Simonelli \& Camaroto, 2011). Information is another constraining factor because the organizations do not know how to map the existing vacancies for PWD and what adaptations could be made with efficiency and low cost (Belizário, 2009).

On the scenario of inclusion of PWDs specific to Brazil, studies consider that when expectations of the institutional environment appear to be in conflict with business interests, organizations may try to gain legitimacy without necessarily changing business practices. In this way, they opt for the apparent adoption of structures that comply with institutional demands, but that are disconnected from the real practice, such as the inclusion of PWD (Meyer \& Rowan, 1977; Oliver, 1991; Scott, 1995; Westphal \& Zajac, 1994).

Sometimes, though stating that it complies with the quotas determined by law, the organization does not make changes in its practices so that the inclusion is really legitimate. In this sense, a concept that can help to understand how organizations deal with the need to adapt their practices to a social demand, such as the inclusion of PWD, at the same time as they seek their survival is the ceremonialism explored in institutional theory. Thus, in the literature on this theory, the concept of ceremonialism was sought. The next section aims to understand how legal demands can influence organizational behavior and how organizations can respond to the specificities of each context, according to their interests, values, and strategies. 


\section{CEREMONIALISM IN ORGANIZATIONAL PRACTICES}

When expectations of the institutional environment appear to conflict with business interests, organizations may try to gain legitimacy without necessarily changing organizational practices. They have opted for the apparent adoption of structures that may seem similar to institutional demands, but which are disconnected from everyday organizational practice (Meyer \& Rowan, 1977; Oliver, 1991; Scott, 1995; Westphal \& Zajac, 1994).

Organizational management practices are highly conditioned by different institutions at the national level, and the institutional profile of a country is complex and involves different institutional dimensions (Aguilera-Caracuel \& Ortiz-de-Mandojana, 2013). Organizations that fit into a new context need to consider two national dimensions that clearly define how different countries respond to regulatory and regulatory issues.

Managing compliance with externally imposed legal and regulatory requirements is a challenge for many organizations, especially when these requirements appear to be in conflict with profit maximization activities. Resolving this tension is critical for organizations to acquire and/or maintain legitimacy before regulatory agencies and legislators and society (Maclean \& Behnam, 2010).

Considering the forms of organizational response to the new demand, institutional theory draws a distinction between ceremonial or superficial adoption and substantive changes to show the differences between practices adopted and actual operating practices (Kostova, Roth, \& Dacin, 2008). Fiss and Zajac (2006) term this mechanism of organizational action "symbolic adoption" - that is, a superficial adoption, without any effective change in the current organizational processes. This is the kind of mechanism by which organizational legitimacy is strengthened while internal power relations are left virtually unchanged.

This organizational behavior can be explained by the costs of change, which can be so high that organizations are more likely to resist external expectations and try to influence key stakeholders through strategic manipulation rather than substantive change (Fiss \& Zajac, 2004, 2006; Scherer, Palazzo, \& Seild, 2013). The propensity to maintain the previous organizational practices untouched is not the unique mechanism of organizations, because inspection agents may also accept the credentials and ambiguous goals that are characteristic of ceremonial organizations (Meyer \& Rowan, 1977). 
However, it is worth emphasizing that a process of adopting symbolic practices may not be linked to the organization as a whole, because all organizational levels are subject to pressures, and organizational and institutional changes are often uneven and irregular, affecting one part of the organization rather than another (Bromley \& Powell, 2012). This organizational behavior can be explained through the change costs (Scherer, Palazzo \& Seild, 2013). When the costs of change are high, organizations are more likely to resist external expectations than to make substantive changes (Fiss \& Zajac, 2004, 2006; Scherer et al., 2013).

The process of perpetuating organizational practices may be linked to the dependency relationship between subsidiaries and the parent company, which would lead to knowledge sharing between the headquarters and subsidiary and replication of practices. This is because when knowledge becomes routine, it becomes a recurring pattern of action (Berger \& Luckman, 2009). As time goes on, the subsidiary's history is built on a shared knowledge pool. Actions and actors become typified. Meanings and shared behaviors facilitate coordination activities, making behaviors understandable, predictable, and stable (Berger \& Luckman, 2009).

In short, the study of the learning process of diversity practices for PWD in Brazilian organizations can benefit from incorporating the concept of ceremonialism, coming from institutional theory. It is not a question of using institutional theory, but rather of summoning a concept from within this field that can help us to understand the phenomenon circumscribed herein from the perspective of practices. This concept can contribute to understanding why the institutionalized practice's absorption in a multinational company's headquarters may or may not be the same in the subsidiary, considering the pressures imposed by the context (Scott, 1995). In the next section, we present the relationship between learning, ceremonialism, and diversity practices for PWD in the context of multinational companies from the perspective of organizational learning based on practice.

\section{ORGANIZATIONAL LEARNING AND CEREMONIALISM IN DIVERSITY PRACTICES IN MULTINATIONAL ENTERPRISES}

This essay considers OL a process of collective knowledge construction and change which is produced and modified through practices, incorporating not only cognitive but also social aspects. The construction of knowledge 
implies its creation, sharing, and institutionalization within a social and historical context, impacting on what was learned previously and how responses to new events are elaborated (Fortis, Maon, Frooman, \& Reiner, 2016; Gherardi, 2000, 2009a; Patriotta, 2003; Shrivastava, 1983). Table 1 shows the categories proposed for the construction of the model proposed in this essay.

\section{(Table 1) \\ CATEGORIES OF STUDY}

\begin{tabular}{|c|c|c|}
\hline CATEGORIES & DEFINITIONS & SCHOLARS \\
\hline $\begin{array}{l}\text { Organizational } \\
\text { learning }\end{array}$ & $\begin{array}{l}\text { OL is a process of collective knowledge construction } \\
\text { and changes that are produced and modified through } \\
\text { practices incorporating not only cognitive but also } \\
\text { behavioral and cultural aspects. Knowledge construction } \\
\text { implies a process of how it is produced, how it circulates, } \\
\text { and how it is institutionalized within a social and } \\
\text { historical context that impacts on what has been } \\
\text { learned previously and how responses to new events } \\
\text { are elaborated. }\end{array}$ & $\begin{array}{l}\text { Fortis et al., } 2016 \\
\text { Gherardi, 2000, } 2009 \text { b } \\
\text { Shrivastava, } 1983 \\
\text { Patriotta, } 2003 \\
\text { Takahashi, } 2007\end{array}$ \\
\hline $\begin{array}{l}\text { Diversity } \\
\text { practices }\end{array}$ & $\begin{array}{l}\text { Diversity practices refer to substantive organizational } \\
\text { efforts to provide an inclusive culture that values } \\
\text { differences and promotes opportunities for all } \\
\text { employees. }\end{array}$ & Esen, 2005 \\
\hline Ceremonialism & $\begin{array}{l}\text { Ceremonial practices are organizational actions that } \\
\text { attempt to assure organizational legitimacy vis-à-vis } \\
\text { the external public through the adoption of products, } \\
\text { services, techniques, policies or programs that, } \\
\text { contradicting the efficiency criterion, are adopted by } \\
\text { the organization to comply with institutional demands } \\
\text { motivated by organizational survival. }\end{array}$ & Meyer \& Rowan, 1977 \\
\hline
\end{tabular}

Source: Elaborated by the authors.

Human relation dynamics in organizations are both a source of learning and knowledge and constitute the environment where knowledge and learning are built (Billet, 2004), because knowledge is dependent on context and how people perceive it (Schulz, 2003). This is due to the fact that the specific knowledge of an organization is shared and often converted into standard operating procedures, routines, and rules (Huber, 1991; Levitt \& March, 1988; Schulz, 2003). Knowledge construction in organizations does not have a close and direct relationship with performance, control, 
or competition, but it is imbricated in sense-making, existence, and the ontology of the individual (Lanzara \& Patriotta, 2001). This reveals that situated actions, learning experiences, and changes experienced over time direct the actors' efforts to explain controversies and anticipate their actions to solve problems (Lanzara \& Patriotta, 2001; Schulz, 2003).

When headquarters' prior knowledge is applied to a new environment, its meaning and potential to inform or initiate an action are subject to change in accordance with the dominant cultural attributes in the subsidiaries. In this sense, aspects such as value systems and cultural assumptions of the subsidiaries' countries may indicate the need to reflect on local organizational practices and knowledge in order to obtain synergy between interaction and learning, where knowledge, values, and experiences are used within the multicultural domains in which MNEs operate (Søderberg \& Holden, 2002).

The OL investigation process in this work is focused on diversity practices, such as the inclusion of PWD, practices which are portrayed here as an example of legal pressure for inclusion in organizations. Several authors point out that diversity in organizations does not happen without tensions and it is in this regard that learning theory can contribute to understanding how organizations articulate knowledge and develop practices to promote inclusion. As Antonacopolou and Chiva (2007) point out, the actors' interactions are not only governed by their action, but also by their intentions that are often under tension. Thus, the organization's intention to develop diversity policies can be influenced both by the perceived tension in its environment and by that present in its social interactions. These tensions can give rise to different possibilities for action that amplify their present modes, revealing the political nature of learning and allowing flexibility and different possibilities for the positioning of the organization.

However, an organization can adopt a ceremonial practice as a way to obtain legitimacy for its actions in the new context where it is inserted. Despite being contrary to the criterion of efficiency, ceremonial practices are adopted to comply with institutional demands as a way of seeking organizational survival (Meyer \& Rowan, 1977; Scott, 1995; Westphal \& Zajac, 1994). When an organization needs to adopt a practice based on demand from its environment, it may consider that compliance is something that hampers the development of its regular activities. Consequently, the organization can merely indicate its obedience to the institutionalized rules without necessarily applying them in their totality, adopting a ceremonial stance, which prevents the renewal of organizational knowledge (Fiss \& Zajac, 2001). 
From the considerations presented in this section, it is possible to perceive that the inclusion of practices of diversity in the organizational context requires organizational actors to reflect on their way of acting. This is because, from the interaction between new entrants, new practices are necessary for organizational integration. For the inclusion of diversity in the work context, the organization can carry out a process of transformation of the attitudes and thoughts of the organization members as a way to take advantage of what diversity can bring in terms of contribution to the organization. In this case, the change of thinking and attitudes for the inclusion of diversity is supported by a learning process, and studying it allows us to understand how the organization learns (Argote \& Miron-Spektor, 2011).

It is argued that there is a relationship between the degree of depth of the organizational learning process and the type of diversity practices performed, ceremonial or substantive. Ceremonial practices are discursive practices detached from reality, focused on organizational legitimacy. Substantive practices are here defined as those practices that are sustained by organizational values and considered in the opposite sense to ceremonial practices. Thus, the implementation of substantive diversity practices is supported by a high-level organizational learning process (Barr, Stimpert, \& Huff, 1992; Fiol \& Lyles, 1985), implying a flow of knowledge that involves the institutionalization of knowledge about working together with diversity.

Many organizations already experience the need to insert diversity in their work context, so that when they begin to work in other countries, this issue is not so new in their activities and, over time, they construct knowledge about diversity insertion. However, in some countries, the insertion of diversity is not a demand and, when an organization moves into a new environment, the need to insert diversity into the organizational context can be considered a new demand.

Finally, it is considered here that the type of diversity practices developed in the subsidiary can occur in a convergent or divergent way from the practices of the headquarters. If the headquarters are situated in a country whose legal context does not demand these practices and it does not actually have diversity practices, it is up to the subsidiary to create its own practices, which may be ceremonial or substantive. Thus:

Proposition 1. When the MNE headquarters do not have diversity practices and the subsidiary creates substantive practices, there is a process of collective knowledge change in the subsidiary that modifies and creates new practices that alter organizational values, resulting in a higher level learning process related to diversity. 
Proposition 2. When the MNE headquarters do not have diversity practices and the subsidiary creates ceremonial practices, there is no process of building and changing collective knowledge in the subsidiary that modifies or creates new practices and changes organizational values, resulting in a process of lower level learning related to diversity.

When the subsidiary is inserted in a context where there is a legal framework for diversity insertion, as in the Brazilian case of PWD inclusion, and the headquarters also have diversity practices related to PWD, the subsidiary can present two types of behavior: a) adopt ceremonial practices of diversity, since it does not have values aimed at inclusion; in this way, it tries to demonstrate to the society that it has diversity practices, but without changing the way in which it manages its activities; or b) adopt substantive practices of diversity, based on organizational values that recognize the importance of inclusion. In both situations, the subsidiary can either absorb practices already institutionalized in the headquarters or create its own practices, if the headquarters do not have them. Therefore, the subsidiary can absorb or create practices, and these can be ceremonial or substantive.

These different positions imply a specific level of adoption of diversity practices. Table 2 below expresses possible behaviors of subsidiaries in relation to headquarters' practices located in countries with and without laws regulating the inclusion of diversity. It is considered that the headquarters can even have such practices inserted in a country without legal regulation, either in line with its own values or according to other interests, such as image concerns.

\section{(Table 2)}

\section{DIVERSITY PRACTICES OF THE BRAZILIAN SUBSIDIARY IN RELATION TO PRACTICES OF THE HEADQUARTERS}

\begin{tabular}{lccccc}
$\begin{array}{c}\text { Head- } \\
\text { quarters }\end{array}$ & $\begin{array}{c}\text { With law and } \\
\text { ceremonial } \\
\text { practices }\end{array}$ & $\begin{array}{c}\text { With law and } \\
\text { substantive } \\
\text { practices }\end{array}$ & $\begin{array}{c}\text { Without law } \\
\text { or practice }\end{array}$ & $\begin{array}{c}\text { Without } \\
\text { law with } \\
\text { ceremonial } \\
\text { practices }\end{array}$ & $\begin{array}{c}\text { Without } \\
\text { law with } \\
\text { substantive } \\
\text { Ceremonial } \\
\text { practices }\end{array}$ \\
\hline $\begin{array}{l}\text { Substantive } \\
\text { practices }\end{array}$ & Absorbs & Creates & Creates & Absorbs & Creates \\
\hline
\end{tabular}

Source: Elaborated by the authors. 
The columns in Table 2 represent possible contextual situations of the headquarters where they may or may not be laws for the inclusion of diversity in the work environment, and which may or may not have diversity practices. The rows express the two possibilities for the subsidiary situated in a context with legal regulation: to have ceremonial practices or substantive practices.

When the headquarters are located in a country with legal regulations and have ceremonial practices, the subsidiary can reproduce these practices by absorbing them or by creating substantive practices, grounded in their values of inclusion. However, if these headquarters have substantive practices, the subsidiary can absorb them by maintaining practices aligned with those of the headquarters, or can create ceremonial practices due to a detachment caused by some contextual or situational motive. If the headquarters do not have diversity practices due to a lack of legal pressure or by choice, it is up to the subsidiary to create practices which may be ceremonial, because there is no culture of inclusion values, or substantive, based on inclusion values.

If the headquarters are in a context without legal regulations but still have diversity practices, either by choice or because of organizational culture issues, the subsidiary may follow headquarters' practices or not. In cases where the headquarters have ceremonial practices of diversity, the subsidiary may absorb these practices or create different, substantive practices. In cases where the headquarters have substantive diversity practices, the subsidiary may absorb substantive practices or create ceremonial practices.

In this way, diversity practices in a subsidiary located in a country with legal regulations such as Brazil can be ceremonial or substantive, in agreement or not with the practices of the headquarters (if they have any). Headquarters' posture may reflect the behavior of the subsidiary or not and, consequently, will imply different learning processes regarding existing practices for the inclusion of diversity.

If the headquarters do not have diversity practices and the subsidiary develops ceremonial practices, learning will be at a lower level, since there will be changes of small impact in a given activity, based on a functional rationality and focused on a prioritized concern with image and legitimacy. If the headquarters do not have diversity practices and the subsidiary develops substantive practices, learning will be at a higher level, since there will be a search for new knowledge, skills development and changes in the interpretive schemes (Fiol \& Lyles, 1985). 
When headquarters, located in a country with or without legal regulations, have diversity practices, and a subsidiary located in a country with legal regulations such as Brazil (or even in another country with or without regulation, but with diversity practices) also has diversity practices, four possibilities for action of the subsidiary emerge, with different implications for the organizational learning process. Figure 1 presents the model proposed from these possibilities.

\section{(Figure 1)}

\section{DIVERSITY PRACTICES IN MNES' SUBSIDIARIES AND LEARNING PROCESS}

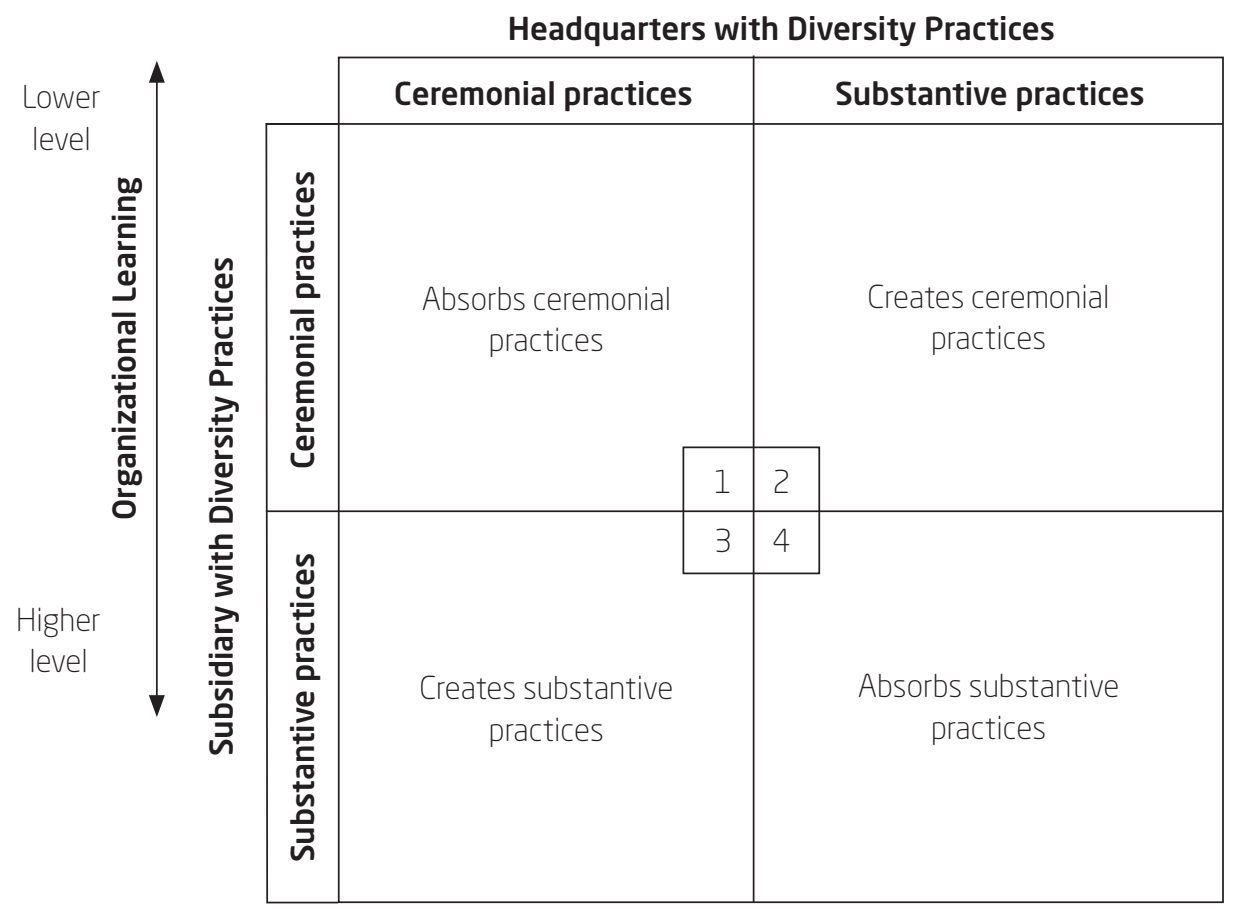

Source: Elaborated by the authors.

Figure 1 shows different possibilities for diversity practices in subsidiaries whose headquarters also have these practices. On the axis concerning the headquarters, it is considered that they can have ceremonial practices, only tending to a legal aspect or rational interests of the market, or they can have substantive practices, based on organizational values that privilege diversity. Likewise, on the subsidiaries' axis, it is considered that 
they may have ceremonial or subsidiary practices, similar to or different from the headquarters. For each combination, there is a situation of absorption or creation of practices that may be ceremonial or substantive, and in the different situations there is a differentiated process of learning in organizations.

The learning process related to diversity practices is different according to the degree of cognitive, cultural, and behavioral change that has occurred, with the possibility of it being of a lower or higher level (Fiol \& Lyles, 1985), single loop or double loop (Argyris \& Schön, 1978), or low or high degree (Barr et al., 1992). Lower level learning is observed when there is a repetition of previous organizational behavior and minor adjustments are driven in part by what the organization does, with little change in organizational routines. In the case of ceremonial practices, there are few effective changes in the organization since there is a disconnection between practices and organizational structures, although it guarantees legitimacy by tending to institutional demands.

When ceremonial practices are created or absorbed, the necessary knowledge is kept to a minimum so that the required actions are implemented, although the discourse may deny it, and there is no internalization of new knowledge that has an impact on organizational values. On the other hand, higher level learning occurs when there is development of more complex knowledge associations which modify the current state of knowledge and affect the organization as a whole, developing new skills (Fiol \& Lyles, 1985), as in the case of the creation or absorption of substantive practices.

It should be noted that the process and outcome of learning can be modified over time if an organization migrates, for example, from ceremonial practices to substantive practices, because the positions of the practices are not merely dichotomous. When the organization goes through a process of shifting from ceremonial to substantive practices, which implies a greater degree of knowledge created, used, and institutionalized in the organization, it also changes its values and can go through a higher level learning process.

In quadrant 1 , the MNE headquarters have ceremonial practices of diversity geared more towards complying with a legal requirement than based on organizational values that recognize diversity. In this scenario, the subsidiary located in another country absorbs the ceremonial practices already existing in the headquarters by copying them. Knowledge has already been institutionalized in the headquarters without any modification of knowledge in the subsidiary. Thus, there are no changes in practices or creation of new practices, but rather the absorption of those existing in the 
headquarters. Practices are absorbed only for legal compliance and there is no search for new knowledge. What one may observe are adjustments to the organizational procedures to tend to external pressure. The process of learning diversity practices in this situation is lower level (Fiol \& Lyles, 1985), low degree (Barr et al., 1992), or single loop (Argyris \& Schön, 1978), since the subsidiary only reproduces what is already done in headquarters. Based on the literature and what has been discussed above, one can make the following conjecture:

Proposition 3. When the MNE's headquarters have ceremonial practices and the subsidiary absorbs these practices, there is no process of construction and change of the collective knowledge in the subsidiary that modifies or creates new practices and changes the organizational value, resulting in a lower level learning process related to diversity.

The perspective presented in quadrant 2 shows a situation where the MNE headquarters have substantive practices backed up by inclusion values of diversity. However, the subsidiary creates ceremonial practices, imitating the values of the headquarters but keeping the focus only on complying with a legal requirement, which does not demand deep knowledge related to inclusion and therefore will not imply significant change. By disregarding the diversity values of headquarters and detaching itself from its substantive diversity practices, the subsidiary makes few adjustments to organizational procedures and there is no new knowledge flow related to substantive practices. In this scenario, the learning process of diversity practices is lower level (Fiol \& Lyles, 1985), low degree (Barr et al., 1992), or single loop (Argyris \& Schön, 1978), although headquarters have probably experienced a higher level learning process. In this case, it may be considered that:

Proposition 4. When the MNE's headquarters have substantive practices of diversity and the subsidiary creates ceremonial practices, there is no process of building and changing collective knowledge in the subsidiary that modifies or creates new practices and changes organizational values, resulting in a lower level learning process related to diversity.

In quadrant 3, the MNE headquarters have ceremonial practices designed to meet a legal requirement and not based on organizational values that recognize diversity. However, if the subsidiary, even with headquarters having ceremonial practices, creates its own substantive practices of diversity, it will seek and internalize knowledge related to inclusion, which will imply significant changes in organizational practices. In this case, the development 
of new skills will occur (Fiol \& Lyles, 1985) and changes in the subsidiary's understanding (Barr et al., 1992) of how diversity practices should be. The learning process in the subsidiary will be of a higher level (Fiol \& Lyles, 1985), high degree (Barr et al., 1992), or double loop (Argyris \& Schön, 1978), although headquarters probably did not experience this learning process at the organizational level. This action of the subsidiary against impinged demand can provide evidence that:

Proposition 5. When the MNE's headquarters have ceremonial practices of diversity and the subsidiary creates substantive practices, there is a process of collective knowledge change in the subsidiary that modifies and creates new practices sustained by organizational values of inclusion, resulting in a higher level learning process related to diversity.

Finally, in quadrant 4 , it is observed that the MNE headquarters have substantive practices of diversity based on organizational values that recognize the importance of inclusion, and the subsidiary presents the same values and practices of diversity institutionalized in the headquarters. Knowledge and skills of inclusion in the headquarters are shared with the subsidiary, with the development of skills (Fiol \& Lyles, 1985) and changes in the subsidiary's understanding of diversity (Barr et al., 1992). The learning process of diversity practices is higher level (Fiol \& Lyles, 1985), high degree (Barr et al., 1992), or double loop (Argyris \& Schön, 1978), because although headquarters possesses these practices, the subsidiary must learn them as a practitioner. Absorbing substantive practices does not correspond to the same process of absorbing ceremonial practices, since only the former demand the internalization of values that underpin substantive practices. The internalization of these values demands the institutionalization of knowledge and practices that enter the organizational every day and are not only focused on legitimacy but are geared towards actually being included in the world of work. From this configuration of the subsidiary, the following proposition can be presented:

Proposition 6. When the MNE's headquarters have substantive practices of diversity and the subsidiary absorbs these practices, there is a process of construction and change of collective knowledge in the subsidiary that modifies or creates new practices and that changes the organizational values, resulting in a higher level learning process related to diversity.

Thus, the OL process can occur at different levels depending on behavior for the absorption or creation of diversity practices. Learning is dependent on 
prior knowledge, organizational culture, and how the organization modifies its cognitive structures to cope with new events.

When considering MNEs' context, one factor that influences the learning process is the culture of each country and interaction among organizational actors, since the worldview of each individual reveals their identification or not with the organizational principles. Likewise, a shared world view among the members of a subsidiary reveals its identification or not with headquarters. By sharing their institutionalized practices with another context, headquarters need to consider how the process and objectives of translating practices are received by members of the subsidiary.

Social interaction, identification of members with certain practices, and organizational culture are relevant elements for the organization to incorporate or not incorporate new practices demanded by the institutional environment. MNEs deal with the institutional and social demands of each country where they are installed and need to consider the internal consistency of their practices and how to share these practices with subsidiaries (Arslan, 2012).

\section{CONCLUSIONS}

Learning studies based on practice in complex contexts such as multinational companies need to consider the relationship between headquarters and subsidiaries through a specific research model that also includes categories that intervene in the process.

In view of discussions raised in this essay, a theoretical model was presented for the study of learning MNEs' context for diversity inclusion in the work environment, considering the presence of ceremonialism. This proposal follows Argote and Miron-Spektor's (2011) considerations that encourage new research proposals that seek to elucidate how different contextual conditions interact with one another, the organization experience, and its influence on the learning process. In this respect, approaching the legal environment as a factor influencing learning and knowledge relations contributes to understanding different perceptions of organizations about practices demanded by society. Different institutional legacies may impact on the ability to absorb practices, and even when they reach their absorption, they can be transformed from a process of reflection (Batt, Holman, \& Holtgrewe, 2009). 
To reflect on organizational practices, the perspective of the inclusion of PWD is suggested, as it happens in Brazil, showing itself as an environmental demand that can lead the organization to modify its practices and conduct a learning process. Discussions about the inclusion of diversity highlight that, when regulated by the organization, the "different" can become a source of improvement in the learning process and organizational knowledge. This is due to the fact that social interactions of different groups can create new perspectives, new forms of thinking and attitudes that lead to the improvement of organizational practices.

However, this process is not always successful because sometimes organizations fail to carry out the adaptation process efficiently and run into difficulty incorporating new principles and methodologies, which restricts their ability to react to changes that are made necessary (Antonello, 2005). This is relevant to understanding the dynamics of MNEs' pressures and the process of their sharing practices at the global level. If an institutionalized practice is not consistent with the institution and the cognitive framework of a country in which it is installed, there may be difficulty for members of the subsidiary and headquarters in interpreting and judging the practice correctly. In this case, a question that arises is about the capacity of headquarters to interpret institutional pressure and to respond to it in the best possible way (Kostova, 1999).

The differences between MNEs' actions pervade investment in learning and how the MNEs manage and invest in the process of acquiring and creating knowledge bases for the construction of new capacities according to their experience in each locality (Figueiredo, 2011). When expectations of the institutional environment seem to conflict with business interests, organizations may try to gain legitimacy without necessarily changing business practices. In this way, they opt for the apparent adoption of structures that comply with institutional demands, but which are disconnected from the real practice (Meyer \& Rowan, 1977; Oliver, 1991; Scott, 1995; Westphal \& Zajac, 1994).

The adoption of ceremonial practices can prevents the renewal of organizational knowledge (Fiss \& Zajac, 2001). Where the inclusion of PWD is concerned, it should be emphasized that simply hiring, as many organizations believe, does not make them an inclusive company (Fernandes \& Silva, 2008). According to the organizational view on inclusion, different postures can be adopted which can lead to different levels of learning for diversity. Thus, considering the different possibilities in the adoption of diversity practices, the study of OL is a way of contributing to an increase 
in the knowledge of how the practices and lines of action adopted by an organization influence construction of its knowledge and its learning process.

\section{REFERENCES}

Achcaoucou, F., Miravitlles, P., \& Léon-Darder, F. (2014). Knowledge sharing subsidiary R\&D mandate development: A matter of dual embeddedness. International Business Review, 23, 76-90. doi 10.1016/j.ibusrev.2013.08.006 Agócs, C., \& Burr, C. (1996). Employment equity, affirmative action and managing diversity: Assessing the diferences. International Journal of Manpower, 17(4/5), 30-45. doi 10.1108/01437729610127668

Aguilera-Caracuel, J., \& Ortiz-De-Mandojana, N. (2013). Green innovation and financial performance: An institutional approach. Organization $\mathcal{E}$ Environment, 26(4), 365-385. doi 10.1177/1086026613507931

Alves, M. A., \& Galeão-Silva, L. G. (2004). A crítica da gestão da diversidade nas organizações. Revista de Administração de Empresas, 44(3), 20-29. doi 10.1590/S0034-75902004000300003

Ambos, T. C., \& Ambos, B. (2009). The impact of distance on knowledge transfer effectiveness in multinational corporations. Journal of International Management, 15, 1-14. doi 10.1016/j.intman.2008.02.002

Antonacopoulou, E. P. (2009). Impact and scholarship: Unlearning and practising to cocreate actionable knowledge. Management Learning, 40(4), 421-430. doi 10.1177/1350507609336708

Antonacopoulou, E., \& Chiva, R. (2007). The social complexity of organizational learning: The dynamics of learning and organizing. Management Learning, 38(3), 277-295. doi 10.1177/1350507607079029

Antonello, C. S. (2005). A metamorfose da aprendizagem organizacional: Uma revisão crítica. In R. L. Ruas, C. S. \& Boff, L. H. (Orgs.). (2005). Aprendizagem Organizacional e Competências (pp. 12-33). Porto Alegre, RS: Bookman. Antonello, C. S., \& Godoy, A. S. (2010). A encruzilhada da aprendizagem organizacional: Uma visão multiparadigmática. Revista de Administração Contemporânea, 14(2), 310-332. Retrieved from http://producao.usp.br/ handle/BDPI/6251

Argote, L. (2011). Organizational learning research: Past, present and future. Management Learning, 42(4), 439-446. doi 10.1177/1350507611408217 
Argote, L., \& Miron-Spektor, E. (2011). Organizational learning: From experience to knowledge. Organization Science, 22(5), 1123-1137. doi 10.1287/orsc. 1100.0621

Argyris, C., \& Schön, D. A. (1978). Organizational learning: A theory of action perspective. Workingham: Addison-Wesley.

Arslan, A. (2012). Impacts of institutional pressures and the strength of market supporting institutions in the host country on the ownership strategy of multinational enterprises: Theoretical discussion and propositions. Journal of Management \& Governance, 16, 107-124. Retrieved from http://hdl.handle. net/10.1007/s10997-010-9146-1

Barr, P. S., Stimpert, J. L., \& Huff, A. S. (1992). Cognitive change, strategic action, and organizational renewal. Strategic Management Journal, 13, 15-36. Retrieved from http://www.jstor.org/stable/2486350

Batt, R., Holman, D., \& Holtgrewe, U. (2009). The globalization of service work: Comparative institutional perspectives on call centers. Introduction to a Special Issue of the Industrial \& Labor Relations Review, 62 (4), 451-488. Retrieved from http://digitalcommons.ilr.cornell.edu/articles/949

Belizário, M. (2009). Empregabilidade: uma ponte a construir. In A. Schwarz, \& J. Haber. Cotas: Como vencer os desafios da contratação de pessoas com deficiência (pp. 14-16). São Paulo: i.Social. Retrieved from https://vidamaislivre.com. br/uploads/isocial/livro-cotas.pdf

Berger, P. L., \& Luckmann, T. (2009). A construção social da realidade (13 ed.). Petrópolis, RJ: Vozes.

Billett, S. (2004). Workplace participatory practices: Conceptualizing workplaces as learning environments. Journal of Workplace Learning, 16(6), 312-324. doi 10.1108/13665620410550295

Bleijenbergh, I., Peters, P., \& Poutsma, E. (2010). Diversity management beyond business case. Equality, Diversity and Inclusion: An International Journal, 29(5). doi 10.1108/02610151011052744

Bodenhausen, G. V. (2009). Diversity in the person, diversity in the group: Challenges of identity complexity for social perception and social interaction. European Journal of Social Psychology, 40, 1-16. doi 10.1002/ejsp.647

Boyle, B., Nicholas, S., \& Mitchell, R. (2012). Sharing and developing knowledge of organizational culture during international assignments. International Journal of Cross Cultural Management, 12(3), 361-378. doi $10.1177 / 1470595812440151$

Brdulak, H. (2008). Diversity management as a business model. Kobieta $i$ Biznes, 1(4). Retrieved from http://www.scielo.br/scielo.php? script=sci nlinks\&pid=S1678-6971201500020015700009\&lng $=$ en 
Bromley, P., \& Powell, W. W. (2012). From smoke and mirrors to walking the talk: Decoupling in contemporary world. The Academy of Management Annals, 1-48. doi 10.1080/19416520.2012.684462

Brown, J. S., \& Duguid, P. (2001). Knowledge and organization: A socialpractice perspective. Organization Science, 12(2), 198-213. Retrieved from http://pubsonline.informs.org/doi/ref/10.1287/orsc.12.2.198.10116

Chiva, R., Alegre, J., \& Lapiedra, R. (2007). Measuring organisational learning capability among the workforce. International Journal of Manpower, 28(3/4), 224-242. doi 10.1108/01437720710755227

Colakoglu, S., Yamao, S., \& Lepak, D. (2014). Knowledge creation capability in MNC subsidiaries: Examining the roles of global and local knowledge inflows and subsidiary knowledge stocks. International Business Review, 23(1), 91-101. doi 10.1016/j.ibusrev.2013.08.009

Cook, S. D. N., \& Yanow, D. (1993). Culture and organizational learning. Journal of Management Inquiry, 2(4), 373-390. doi 10.1177/105649269324010 Cox, T., \& Beale, R. L. (1997). Developing competency to manage diversity. San Francisco, CA: Berrett-Koehler.

Crespo, C. F.; Griffith, D. A.; Lages, L. F. (2014). The performance effects of vertical and horizontal subsidiary knowledge outflows in multinational corporations. International Business Review, 23, 993-1007. doi 10.1016/j. ibusrev.2014.03.002

Crossan, M. M. et al. (1999). An organizational learning framework: From intuition to institution. The Academy of Management Review, 24(3), 522-537. Retrieved from http://www.jstor.org/stable/259140

Dyck, B., Starke, F. A., Mischke, G. A., \& Mauws, M. (2005). Learning to build a car: An empirical investigation of organizational learning. Journal of Management Studies, 42(2), 387-416. doi 10.1111/j.1467-6486.2005.00501.x Easterby-Smith, M., \& Lyles, M. A. (2011). The evolving field of organizational learning and knowledge management. In M. Easterby-Smith, \& M. A. Lyles (Orgs.). Handbook of organizational learning and knowledge management (2nd ed., pp. 1-20). Sussex, UK: Jonh Wiley and Sons.

Easterby-Smith, M. P. V., Lyles, M., \& Tsang, E. W. K. (2008). Interorganizational knowledge transfer: Current issues and future prospects. Journal of Management Studies. 45(4), 677-690. doi 10.1111/j.14676486.2008.00773.x

Edelman, L. B. (1990). Legal environments and organizational governance: The expansion of due process in the American workplace. American Journal of Sociology, 95(6), 1401-1440. doi 10.1086/229459 
Edelman, L. B. (1992). Legal ambiguity and symbolic structures: Organizational mediation of Civil Rights Law. American Journal of Sociology, 97(6), 1531-1576. doi 10.1086/229939

Edelman, L. B. (2003). Constructed legalities: The endogeneity of law. In W. Powell, \& D. Jones. How institutions change (pp. 55-90). Chicago: University of Chicago Press.

Edwards, T., Marginson, P., \& Ferner, A. (2013). Multinational companies in cross-national context: Integration, differentiation, and the interactions between MNCs and nation States: Introduction to an special issue of the ILR Review. Industrial \& Labor Relations Review, 66(3), 547-587. doi 10.1177/001979391306600301

Elkjaer, B. (1999). In search of a social learning theory. In M. EasterbySmith, J. Burgoyne, \& L. Araújo (Eds.). Organizational learning and the learning organization: Development in theory and practice (pp. 75-91). London: Sage.

Esen, E. (2005). Workplace diversity practices survey report. Alexandria, VA: Society for Human Resource Management. Retrieved from http://www.bus. iastate.edu/emullen/mgmt472/shrmdiversityreport.pdf

Fernandes, A. L., \& Silva, S. M. (2008). Recrutamento e seleção do profissional portador de deficiência nas organizações: integração ou inclusão? Facef Pesquisa, 11(2). Retrieved from http://periodicos.unifacef.com.br/index. php/facefpesquisa/article/view/120/0

Figueiredo, P. N. (2011). The role of dual embeddedness in the innovative performance of MNE subsidiaries: Evidence from Brazil. Journal of Management Studies, 48(2), 417-440. doi 10.1111/j.1467-6486.2010.00965.x

Fiol, C. M., \& Lyles, M. A. (1985). Organizational learning. The Academy of Management Review, 10(4), 803-813. Retrieved from http://www.jstor.org/ stable/258048

Fiss, P. C., \& Zajac, E. J. (2004). The diffusion of ideas over contested terrain: The (non)adoption of a shareholder value orientation among German firms. Administrative Science Quarterly, 49(2), 501-534. Retrieved from http:// journals.sagepub.com/doi/abs/10.2307/4131489

Fiss, P. C., \& Zajac, E. J. (2005). The symbolic management of corporate strategy: Framing, decoupling and strategy change. Academy of Management Journal, 49, 1173-1193.

Fiss, P. C., \& Zajac, E. J. (2006). The symbolic management of strategic change: Sensegiving via framing and decoupling. Academy of Management Journal, 49(6), 1173-1193. doi 10.5465/amj.2006.23478255 
Fortis, Z., Maon, F., Frooman, J., \& Reiner, G. (2016). Unknown knowns and known unknowns: Framing the role of organizational learning in corporate social responsibility development. International Journal of Management Reviews. doi 10.1111/ijmr.12130

Geiger, D. (2009). Revisiting the concept of practice: Toward an argumentative understanding of practicing. Management Learning, 40(2), 129-144. doi $10.1177 / 1350507608101228$

Gertsen, M. C., \& Zølner, M. (2014). Being a ‘modern Indian' in an offshore centre in Bangalore: Cross-cultural contextualization of organizational identification. European Journal of International Management, 8(2), 179-204. doi 10.1504/EJIM.2014.059582

Gherardi, S. (2000). Practice-based theorizing on learning and knowing in organizations. Organization, 7(2), 211-223. doi 10.1177/135050840072001 Gherardi, S. (1999). A symbolic approach to competence development. Human Resource Development International, 2(4), 313-334. doi $10.1080 / 13678869900000036$

Gherardi, S. (2001). From organizational learning to practice-based knowing. Human Relations, 54(1), 131-139. doi 10.1177/0018726701541016

Gherardi, S. (2003). Knowing as desiring: Mythic knowledge and the knowledge journey in communities of practitioners. Journal of Workplace Learning, 15(7/8), 352-358. doi 10.1108/13665620310504846

Gherardi, S. (2009a). Introduction: the critical power of the 'practical lens'. Management Learning, 40(2), 115-128. doi 10.1177/1350507608101225

Gherardi, S. (2009b). Practice? It's a matter of taste! Management Learning, 40(5), 535-550. doi 10.1177/1350507609340812

Gherardi, S., \& Nicolini, D. (2002). Learning in a constellation of interconnected. Journal of Management Studies, 39(4), 419-436. doi 10.1111/1467-6486.t01-1-00298

Gil, M. (Coord). (2002). O que as empresas podem fazer pela inclusão das pessoas com deficiência. São Paulo, SP: Instituto Ethos. Retrieved from https://www3. ethos.org.br/wp-content/uploads/2012/12/25.pdf

Golsorkhi, D. et al. (2010). Introduction: What is strategy as practice? In D. Golsorkhi , L. Roleau, D. Seidl, \& E. Vaara. Cambridge handbook of strategy as practice (pp. 1-20). Cambridge, UK: Cambridge University Press.

Huber, G. P. (1991). Organizational learning: The contributing process and the literatures. Organization Science, 2(1), 88-115. Retrieved from http:// pubsonline.informs.org/doi/abs/10.1287/orsc.2.1.88 
Instituto Brasileiro de Geografia e Estatística (IBGE). (2012). Características da população - censo 2010. Retrieved from http://7a12.ibge.gov.br/vamosconhecer-o-brasil/nosso-povo/caracteristicas-da-populacao.html.

Kasper, H., Lehrer, M., Mühlbacher, J., \& Müller, B. (2013). On the different "worlds" of intra-organizational knowledge management: Understanding idiosyncratic variation in MNC cross-site knowledge-sharing practices. International Business Review, 22(1), 326-338. doi 10.1016/j. ibusrev.2012.05.001

Kostova, T. (1999). Transnational transfer of strategic organizational practices: a contextual perspective. Academy of Management Review, 24(2), 308-324. Retrieved from http://www.jstor.org/stable/259084.

Kostova, T. \& Roth, K. (2002). Adoption of an organizational practice by subsidiaries of multinational corporations: Institutional and relational effects. The Academy of Management Journal, 45(1), 215-233. doi 10.2307/3069293

Kostova, T., Roth, K., \& Dacin, M. T. (2008). Institutional theory in the study of multinational corporations: a critique and new directions. Academy of Management Review, 33(4), 994-1006. doi 10.5465/amr.2008.34422026 Langley, A. et al. (2013). Process studies of change in organization and management: Unveiling temporality, activity and flow. Academic of Management Journal, 56(1), 1-13. doi 10.5465/amj.2013.4001

Lanzara, G., \& Patriotta, G. (2001). Technology and the courtroom: An inquiry into knowledge making in organizations. Journal of Management Studies, 38(7), 943-971. doi 10.1111/1467-6486.00267

Leavitt, C. C. (2011). A comparative analysis of three unique theories of organizational learning. Retrieved from https://eric.ed.gov/?id=ED523990

Levitt, B., \& March, J. G. (1988). Organizational learning. Annual Review of Sociology, 14, 319-338. doi 10.1146/annurev.so.14.080188.001535

Li, S., Bartunek, J. M., \& Easterby-Smith, M. P. V. (2009). Research methods for organizational learning: the transatlantic gap. Management Learning, 40(2), 439-447. doi 10.1177/1350507609339682

Maclean, T. L., \& Behnam, M. (2010). The dangers of decoupling: The relationship between compliance programs, legitimacy perceptions, and institutionalized misconduct. Academy of Management Journal, 53 (6), 14991520. doi 10.5465/amj.2010.57319198

Martinez, R. J., \& Dacin, J. M. (1999). Efficiency motives and normative forces: Combining transactions costs and institutional logic. Journal of Management, 25(1), 75-96. doi 10.1177/014920639902500104 
Meyer, J. W., \& Rowan, B. (1977). Institutional organizations: formal structure as myth and ceremony. American Journal of Sociology, 83(2), 340363. Retrieved from http://www.jstor.org/stable/2778293

Muzio, D., \& Faulconbridge, J. (2013). The global professional service firm: 'One firm' models versus (Italian) institutionalized practices. Organization Studies, 34(7), 897-925. doi 10.1177/0170840612470232

Oliver, C. (1991). Strategic responses to institutional process. Academy of Management Review, 16(1), 145-179. doi 10.5465/amr.1991.4279002

Orlikowski, W. J. (2010). Practice in research: Phenomenon, perspective and philosophy. In D. Golsorkhi, L. Roleau, D. Seidl, \& E. Vaara. Cambridge Handbook of Strategy as Practice (pp. 23-33). Cambridge, UK: Cambridge University Press.

Patriotta, G. (2003). Organizational knowledge in the making: How firms create, use, and institutionalize knowledge. New York, NY: Oxford University Press.

Perlin, A. P., Gomes, C. M., Kneipp, J. M., Frizzo, K., \& Rosa, L. A. B. (2016). Inclusão de pessoas com deficiência no mercado de trabalho. Um estudo em uma empresa do setor cerâmico. Desenvolvimento em Questão, 14(34), 214-236. Retrieved from http://www.spell.org.br/documentos/ver/40443/ inclusao-de-pessoas-com-deficiencia-no-mercado-de-trabalho-um-estudoem-uma-empresa-do-setor-ceramico-/i/pt-br.

Phillips, N., \& Tracey, P. (2009). Dialogue. Academy of Management Review, 34(1), 169-171. doi 10.5465/amr.2009.35713350

Prasad, P., Pringle, J. K., \& Konrad, A. M. (2006). Examining the contours of workplace diversity: Concepts, contexts and challenges. In A. M. Konrad, P. Prasad, \& J. K. Pringle. Handbook ok Workplace Diversity (pp. 1-22). Thousand Oaks, CA: Sage.

Raelin, J. A. (2007). Toward an epistemology of practice. Academy of Management Learning E Education Journal, 6(4), 495-519. doi 10.5465/ amle.2007.27694950

RAIS. (2012). Dados Nacionais - 2012. Retrieved from http://acesso.mte.gov. br/data/files/FF8080814F4D225D014FB2490DFB6D67/consolidado\%20 tabelas\%20total.pdf

Ribeiro, M. A., \& Carneiro, R. (2009). A inclusão indesejada: As empresas brasileiras face à Lei de Cotas para pessoas com deficiência no mercado de trabalho. Organização \& Sociedade, 16(50), 545-564. Retrieved from http:// www.repositorio.fjp.mg.gov.br/handle/123456789/100

Roth, K., \& Kostova, T. (2003). The use of the multinational corporation as a research context. Journal of Management, 29(6), 883-902. doi 10.1016/ S0149-2063_03_00083-7 
Scherer, A. G., Palazzo, G., \& Seidl, D. (2013). Managing legitimacy in complex and heterogeneous environments: Sustainable development in a globalized world. Journal of Management Studies, 50(2), 259-284. doi 10.1111/ joms. 12014

Schulz, M. (2003). Pathways of relevance: Exploring inflows of knowledge into subunits of multinational corporations. Organization Science, 14(4), 440459. doi 10.1287/orsc.14.4.440.17483

Shen, J., \& Benson, J. (2014). When CSR is a social norm: How socially responsible human resource management affects employee work behavior. Journal of Management, 42(6), 1723-1746. doi 10.1177/0149206314522300

Simonelli, A. P., \& Camarotto, J. A. (2011). Análise de atividades para a inclusão de pessoas com deficiência no trabalho: Uma proposta de modelo. Gestão \& Produção, 18(1), 13-26. Retrieved from http://www.scielo.br/pdf/ gp/v18n1/02.pdf.

Søderberg, A. M., \& Holden, N. (2002). Rethinking cross cultural management in a globalizing business world. International Journal of Cross Cultural Management, 2(1), 103-121. doi 10.1177/147059580221007

Scott, R. W. (1995). Institutions and organizations. Thousand Oaks, CA: Sage. Shrivastava, P. (1983). A typology of organizational learning systems. Journal of Management Studies, 20(1), 7-28. doi 10.1111/j.1467-6486.1983.tb00195.x Szulanski, G. (1996). Exploring internal stickiness: impediments to the transfer of best practices within the firm. Strategic Management Journal, 17(S2), 27-43. doi 10.1002/smj.4250171105

Ramos Filho, A. C. (2012). Conhecimento e aprendizagem gerencial nas multinacionais brasileiras: Uma abordagem interacionista. Simpósio de Excelência em Gestão e Tecnologia (SEGeT), Resende, Rio de Janeiro, 9. Retrieved from http://www.aedb.br/seget/arquivos/artigos12/53516636.pdf

Spataro, S. E. (2005). Diversity in context: how organizational culture shapes reactions to workers with disabilities and others who are demographically different. Behavioral Sciences and the Law, 23(1), 21-38. doi 10.1002/bsl.623

Takahashi, A. R. W. (2007). Descortinando os processos da aprendizagem organizacional no desenvolvimento de competências em instituições de ensino (Doctoral dissertation). Universidade de São Paulo, São Paulo, SP, Brazil. doi 10.11606/t.12.2007.tde-17102007-160130

Thomas, D. A., \& Ely, R. J. (1996). Making differences matter: A new paradigm for managing diversity. Harvard Business Review, 74(5), 79-90. Retrieved from https://hbr.org/1996/09/making-differences-matter-a-newparadigm-for-managing-diversity

Tilcsik, A. (2010). From ritual to reality: demography, ideology, and decoupling in a postcommunist government agency. Academy of Management Journal, 53 (6), 1474-1498. doi 10.5465/amj.2010.57318905 
Vaara, E., Risberg, A., Søderberg, A. M., \& Tienari, J. (2003). The construction of national stereotypes in a merging multinational. In A. M. Søderberg, \& E. Vaara (Eds.). (2003). Merging across borders: People, cultures and politics (pp. 61-86). Copenhagen, DK: Copenhagen Business School Press.

Westphal, J. D., \& Zajac, E. J. (1993). Substance and symbolism in CEO's long-term incentive plans. Academy of Management Proceedings 1, 232-236. doi 10.5465/ambpp.1993.10316996

Yang, Y., \& Konrad, A. M. (2011). Understanding diversity management practices: Implications of institutional theory and resource-based theory. Group E Organization Management, 36(1), 6-38. doi 10.1177/1059601110390997

\section{$\int$ ABOUT THE AUTHORS}

PAULA SUEMI SOUZA KUABARA

PhD from the Department of Management,

Universidade Federal do Paraná (UFPR).

Professor for the Department of Management,

Universidade Federal do Paraná (UFPR).

Avenida Prefeito Lothário Meissner, 632, Jardim Botânico - Curitiba - PR - Brasil - CEP

80210-170

E-mail: paulakuabara@gmail.com

\section{ADRIANA ROSELI WÜNSCH TAKAHASHI}

$\mathrm{PhD}$ from the Department of Management,

Universidade de São Paulo (USP).

Full Professor at the Department of Management,

Universidade Federal do Paraná (UFPR).

Avenida Prefeito Lothário Meissner, 632, Jardim Botânico - Curitiba - PR - Brasil - CEP

80210-170

E-mail: adrianarwt@terra.com.br

\section{ERRATA}

In the paper "Organizational learning, practices of diversity, and ceremonialism: a study proposal in the multinationals context", published in Revista de Administração Mackenzie - RAM (Mackenzie Management Review), 18(5), pages 169-201:

- At page 169, it should be read at the bottom of the page: "Acknowledgments by supporting research projects that allowed to prepare this article to CNPq (Conselho Nacional de Desenvolvimento Científico e Tecnológico". 